\title{
Mycoplasma isolation in milk samples from dairy herds in Chile
}

\author{
Fernando Ulloa ${ }^{\mathrm{a}, \mathrm{b}}$, Juan P. Soto ${ }^{\mathrm{c}}$, Juan Kruze ${ }^{\mathrm{a}}$, Armin Mella ${ }^{\mathrm{a}^{*}}$
}

\begin{abstract}
Mycoplasma bovine mastitis is a highly contagious disease, usually associated with clinical cases refractory to antibiotic treatment. The aim of this study was the isolation of Mycoplasma species in cattle milk samples from dairy herds in Chile. Bulk tank milk samples selected by convenience from 91 Holstein Friesian dairy herds located in Los Rios (66) and Los Lagos (25), the two most important dairy Regions in the country, were collected. Additionally, 100 individual milk samples from cows with a high incidence of clinical mastitis, refractory to antibiotic therapy, and negative bacteriological results for traditional mastitis pathogens, all from the Biobío Region and received in our diagnostic laboratory, were included. All samples were cultured for 10 days on PPLO medium. The differentiation of suspect colonies between genus Mycoplasma and Acholeplasma was performed by the digitonin test and a specific PCR. The species identification was performed by a M. bovis specific PCR and 16S rRNA sequencing. Mycoplasma was isolated from 3 (3.3\%) bulk tank milk samples and 2 (2\%) individual cow milk samples. All colonies were identified as Mycoplasma by the digitonin test and by a specific PCR. At species level, one strain isolated from a bulk tank milk sample was identified as M. bovis. The remaining two strains isolated from bulk tank milk samples were identified as M. bovigenitalium, while the two strains isolated from milk of individual cows were identified as M. alkalescens. These results show that not only M. bovis is present in Chilean dairy herds, but also other pathogenic species not previously described in Chile such as M. bovigenitalium and M. alkalescens, which pose a potential risk for dairy herds in southern Chile.

Key words: bovine mastitis, Mycoplasma mastitis, dairy herds.
\end{abstract}

\section{INTRODUCTION}

Bovine intramammary infection due to Mycoplasma is an emergent problem in the dairy industry of many countries. In recent years, an increase in Mycoplasma mastitis prevalence has been observed especially associated with large dairy herds (Fox et al 2003, Lysnyansky et al 2016, Nicholas et al 2016, Timonen et al 2017, Gille 2018, Abd El Tawad 2019). This type of infections cause major economic losses because are highly contagious, cannot be detected with conventional culture media, do not respond to antibiotic treatments, can affect multiple quarters, produce a large decrease in milk yield, and infected animals usually must be segregated or culled (Nicholas et al 2016). Common species of Mycoplasma isolated from intramammary infections in cows are $M$. bovis, $M$. californicum, $M$. bovigenitalium, $M$. alkalescens and $M$. canadense. However, M. bovis is the most frequent species and the one that produces the most severe clinical cases (Fox 2012). In cattle, M. bovis has also been associated with pneumonia, arthritis, otitis and reproductive disorders (Nicholas and Ayling 2003, Maunsell et al 2011).

Mycoplasmas are one of the smallest known microorganisms, they lack a cell wall and require special

Received: 18.06.2020.

Accepted: 20.08.2020.

aLaboratorio de Mastitis Bovina, Instituto de Bioquímica y Microbiología, Facultad de Ciencias, Universidad Austral de Chile, Valdivia, Chile.

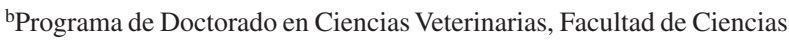
Veterinarias, Universidad Austral de Chile, Valdivia, Chile.

'Prolesur S.A, Quinchilca s/n, Los Lagos, Chile.

*Corresponding author: A Mella; POB 567, Valdivia, Chile; arminmella@ uach.cl media for their in-vitro growth (Razin et al 1998). The routine bacteriological diagnosis procedure for Mycoplasma mastitis is the cultivation of milk samples on special media which are incubated for $7-10$ days at $37^{\circ} \mathrm{C}$ with $10 \% \mathrm{CO}_{2}$ (Hogan et al 1999). The morphological diagnosis is based on recognition of the typical "fried eggs" appearance of the Mycoplasma colonies, and its subsequent identification can be done by serological methods, PCR techniques, $16 \mathrm{~S}$ rRNA gene sequencing, MALDI-TOF and whole genome sequencing (WGS) (Boonyayatra et al 2012, Nicholas et al 2016, Parker et al 2018).

Although the culture of milk samples has a low sensitivity, surveillance using bulk tank milk samples culture for Mycoplasma detection is essential in a Mycoplasma mastitis control program (Fox et al 2003, Wilson et al 2009, Fox 2012). The Mycoplasma mastitis prevalence, based on bulk tank milk culture, varies between countries, e.g. Belgium 1.5\% (Passchyn et al 2012), Israel 2.7\% (Lysnyansky et al 2016), USA 3.2\% (APHIS-USDA. 2008), Japan $3.8 \%$ (Murai and Higuchi 2019) and Grece $5.4 \%$ (Filiousis et al 2007). Sporadic outbreaks have been recently described in some countries but they may be underreported (Nicholas et al 2016).

In Chile, M. bovis had been previously reported in bulk tank milk samples by Sickles et al (2000) and later Bustos and Muñoz (2011) described Mycoplasma spp. in bulk tank milk samples in dairy herds of the Biobio Region. Despite clinical cases of bovine mastitis that are refractory to treatment and culture negative are common in Chilean dairy herds, no more data are available about the presence of Mycoplasma in bulk tank milk and cow milk samples. The aim of this study was the isolation of Mycoplasma species in cattle milk samples from dairy herds in Chile. 


\section{MATERIAL AND METHODS}

\section{MILK SAMPLES COLLECTION}

Ninety-one Holstein Friesian dairy herds from Los Rios (66) and Los Lagos (25), the two most important dairy Regions in the country, were selected by convenience. The herds had between 50 and 400 lactating cows and were providers of the "Sociedad Procesadora de Leche del Sur S.A” (PROLESUR). Most of them were managed under grazing-based systems with concentrate and silage as winter supplementation. Individual milk samples were collected from each bulk milk tank by trained personnel from the PROLESUR company in accordance with the recommendations of the National Mastitis Council, USA (Hogan et al 1999). All the samples were kept and transported at $4{ }^{\circ} \mathrm{C}$ to the laboratory within $8 \mathrm{~h}$ of collection for bacteriological examination. Additionally, 100 individual milk samples from cows with $>500,000$ cells/mL and negative bacteriological results for traditional mastitis pathogens were included. All these milk samples were received in our diagnostic laboratory and came from a dairy herd located in the Biobío Region, with a high incidence of clinical mastitis refractory to antibiotic therapy.

\section{BACTERIOLOGICAL ANALYSIS}

Immediately after arrival at the laboratory, $100 \mu \mathrm{L}$ of each milk sample were plated onto the surface of PPLO Medium (Difco), supplemented with yeast extract, horse serum, salmon DNA, thallium acetate and penicillin and incubated at $37{ }^{\circ} \mathrm{C}$ with $10 \% \mathrm{CO}_{2}$ (Hogan et al 1999). The plates were read at 3, 7, 10 and 12 days of incubation using a stereoscopic microscope (40x), observing all the streaks made on the agar to detect Mycoplasma colonies. At the end of the incubation period, the plates with no growth were discarded and those growing small colonies with a "fried egg" appearance were considered suspicious of Mycoplasma. Then, the surrounding agar of the suspicious colonies was cut out and subcultured into PPLO broth supplemented as mentioned above, and incubated for 3 days at $37{ }^{\circ} \mathrm{C}$ with $10 \% \mathrm{CO}_{2}$, to obtain a pure culture. M. bovis ATCC 25025 strain was used as a positive control for all the tests.

For DNA extraction, $5 \mathrm{~mL}$ of a pure culture was centrifuged at 12,000 g for 30 seconds, the supernatant discarded, and the pellet resuspended in $150 \mu \mathrm{L}$ of PBS, and processed with the commercial kit "AxyPrep Bacterial Genomic DNA Mini-Preparation Kit” (Axygen, Inc.) following the manufacturer instructions.

\section{GENUS IDENTIFICATION}

For the Genus differentiation between Mycoplasma and Acholeplasma, a common environmental organism, the digitonin disk test and a specific PCR test were used
(Boonyayatra et al 2012). The digitonin disk test was performed using a sterile cotton swab moistened with pure culture broth of the suspicious colony, which was inoculated onto the entire surface of a PPLO agar plate. Afterwards, a digitonin disk (Udder Health System, Inc) was placed in the centre of the plate and incubated for 4 days at $37^{\circ} \mathrm{C}$ with $10 \% \mathrm{CO}_{2}$. The presence of a growth inhibition zone surrounding the digitonin disk was visually checked. A clear inhibition zone $>5 \mathrm{~mm}$ from the edge of the disk was considered as a positive test for the genus Mycoplasma. On the contrary, when the growth inhibition zone was $<3$ $\mathrm{mm}$ it was considered as a negative test indicating that the strain belongs to the genus Acholeplasma. In addition, a specific PCR test for genus differentiation was performed using the set of primers F2 5'-GTG(C/G)GG(A/C) TGGATCACCTCCT-3' and R2 5'-GCATCCACCA(A/T) $\mathrm{A}(\mathrm{A} / \mathrm{T}) \mathrm{AC}(\mathrm{C} / \mathrm{T}) \mathrm{CTT}-3$ ' which targets the $16 \mathrm{~S}-23 \mathrm{~S}$ rRNA intergenic spacer region of Mycoplasma and R34 5'-CCACTGTGTGCCCTTTGTTCCT-3' of the 16S23S rRNA intergenic spacer region of Acholeplasma. (Boonyayatra et al 2012). The amplification program was an initial denaturation cycle of 5 minutes at $94{ }^{\circ} \mathrm{C}$, followed by 35 cycles of 30 seconds at $94^{\circ} \mathrm{C}, 2$ minutes at $55^{\circ} \mathrm{C}$ and 2 minutes at $72^{\circ} \mathrm{C}$, with a final extension of 5 minutes at $72^{\circ} \mathrm{C}$. Amplification products were separated by $2 \%$ agarose gel electrophoresis stained with ethidium bromide. The presence of two bands was considered a positive result for Acholeplasma, while Mycoplasma produces only one band.

\section{SPECIES IDENTIFICATION}

Once the suspect strains were confirmed as Mycoplasma, a specific PCR was performed for the identification of $M$. bovis. The primers mb-mp 1F 5' -TATTGGATCAACTGCTGGAT-3 'and mb-mp 1R 5'-AGATGCTCCACTTATCTTAG-3' were used for the amplification of the mb-mp 81 gene, as described by Foddai et al (2005). The thermocycler was set with an initial denaturation cycle of 5 minutes at $94{ }^{\circ} \mathrm{C}$, followed by 30 cycles of 1 minute at $94^{\circ} \mathrm{C}, 1$ minute at 54 ${ }^{\circ} \mathrm{C}$ and 1 minute at $72^{\circ} \mathrm{C}$, with a final extension cycle of 10 minutes at $72^{\circ} \mathrm{C}$. The amplification product was separated by electrophoresis on $2 \%$ agarose gel stained with ethidium bromide. The presence of a band of approximately $447 \mathrm{bp}$ was considered as $M$. bovis. Additionally, all strains were identified by sequencing the $16 \mathrm{~S}$ rRNA gene, according to the protocol described by Botes et al (2005). PCR products of approximately $1048 \mathrm{bp}$ in size were purified using the commercial kit Wizard® SV Gel and PCR CleanUp System (Promega) according to the manufacturer's instructions. Once the PCR products were purified, they were sequenced bidirectionally in MACROGEN (Korea). Consensus sequences were compared to sequences deposited at GenBank using the NCBI's nucleotide-nucleotide BLAST program. An identity above $98.6 \%$ was considered as the same Mycoplasma species (Kim et al 2014). 


\section{RESULTS AND DISCUSSION}

Mycoplasma was isolated in 3 out of 91 (3.3\%) bulk tank milk samples. Typical colonies were $300-400 \mu \mathrm{m}$ in diameter, with a dense central nucleus, surrounded by a lighter peripheral area of growth, which gives it the characteristic "fried egg" appearance (figure 1). Additionally, Mycoplasma was also isolated in 2 out of $100(2 \%)$ individual milk samples from cows with subclinical mastitis. All colonies were identified as belonging to the Mycoplasma genus by both the digitonin and PCR tests. These results show that Mycoplasma is present in dairy herds of southern Chile, however, it must be considered that its presence may be underestimated due to the low sensitivity of a single bulk tank culture. Despite this disadvantage, the quality of the Mycoplasma bulk milk tank culture can be improved by performing three consecutive cultures separated by 3-4 days (Gonzalez and Wilson 2002).

The three isolated strains from bulk tank milk samples were named J14, J35 and J71. Regarding the species identification, only strain $\mathrm{J} 35$ was identified as $M$. bovis by the specific PCR, which produced a band of approximately $447 \mathrm{bp}$ (data not shown), and by partial sequencing of the 16S rRNA gene. Strains J14 and J71 were identified at the species level as $M$. bovigenitalium by partial sequencing of the 16S rRNA gene. The two strains isolated from cases of subclinical mastitis were named V49 and V61, both identified as $M$. alkalescens by partial sequencing of the 16S rRNA gene (table 1).

In Chile, M. bovis had been isolated in 5 out of $71(7 \%)$ bulk milk tank samples of herds from Los Ríos and Los Lagos Regions, from different dairy farms (Sickles et al

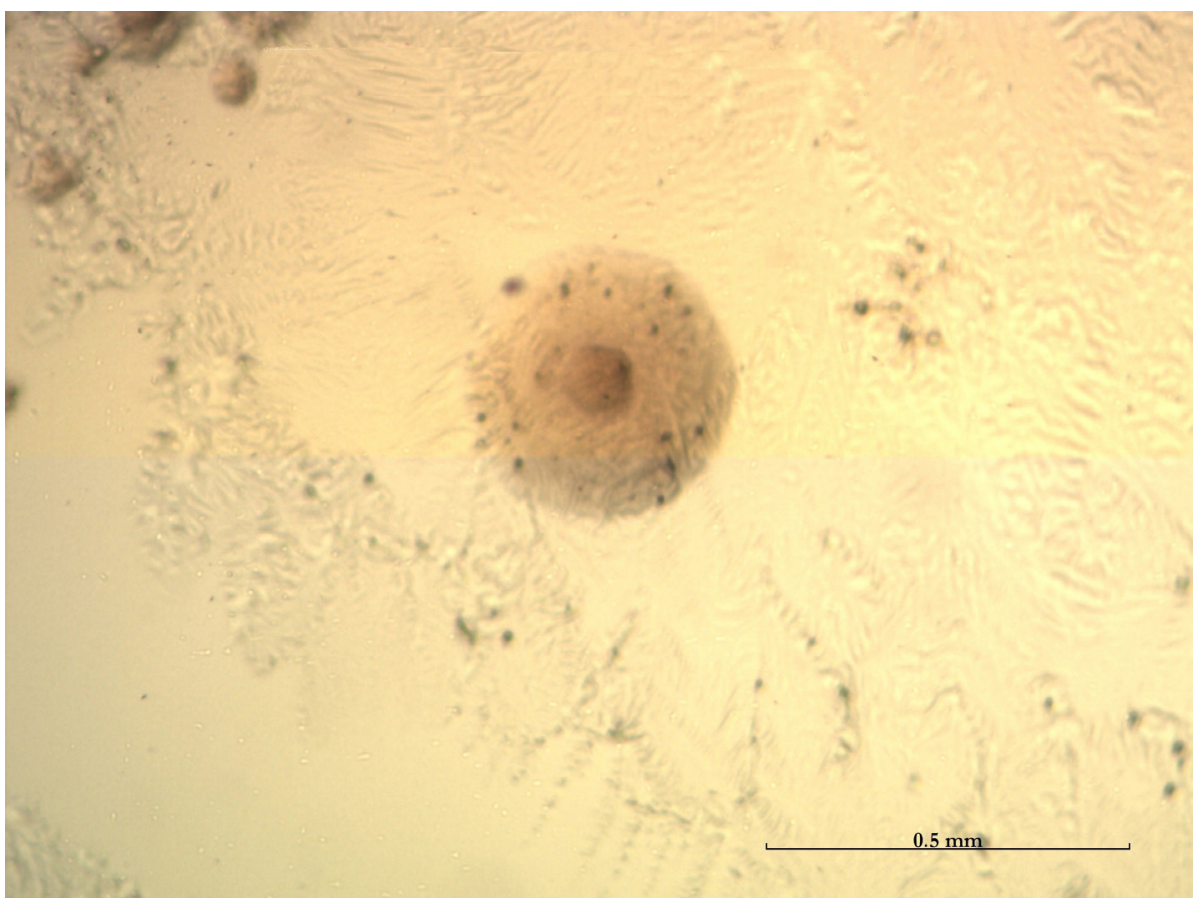

Figure 1. Mycoplasma colony on PPLO agar plate, with typical "egg fried" appearance (400x).

Table 1. Identification of the isolated mycoplasma strains.

\begin{tabular}{|c|c|c|c|c|c|c|c|}
\hline \multirow{2}{*}{ Strain name } & \multirow{2}{*}{ Source } & \multirow{2}{*}{ Digitonin } & \multirow{2}{*}{$\begin{array}{l}\text { PCR Mycoplasma } \\
\text { spp. }\end{array}$} & \multirow{2}{*}{$\begin{array}{l}\text { PCR } M \text {. } \\
\text { bovis }\end{array}$} & \multicolumn{3}{|c|}{ 16s rRNA gene sequencing } \\
\hline & & & & & Aligned strain & Access & Similarity \\
\hline $\mathrm{J} 14$ & BTM $*^{*}$ & + & + & - & $\begin{array}{c}\text { M. bovigenitalium NBRC } \\
14862\end{array}$ & AB680692.1 & $99 \%$ \\
\hline $\mathrm{J} 35$ & BTM* & + & + & + & M. bovis PG 45 & NR102850.1 & $99 \%$ \\
\hline J71 & BTM $*^{*}$ & + & + & - & $\begin{array}{l}\text { M. bovigenitalium NBRC } \\
14862\end{array}$ & AB680692.1 & $99 \%$ \\
\hline V49 & $\mathrm{SCM}^{* *}$ & + & + & - & M. alkalescens PG51 & NR025984.1 & $100 \%$ \\
\hline V61 & $\mathrm{SCM}^{* *}$ & + & + & - & M. alkalescens PG51 & NR025984.1 & $100 \%$ \\
\hline
\end{tabular}

*Bulk tank milk.

**Subclinical mastitis. 
2000). The percentage of Mycoplasma positive milk tanks was higher in this study, but the results are not comparable because in our study we used only samples from suppliers of PROLESUR company. Another Chilean study reports that Mycoplasma was isolated from 4 out of $11(36 \%)$ bulk tank milk samples from the Biobío Region, but the strains isolated were not identified at species level (Bustos and Muñoz 2011). Although the percentage of Mycoplasmapositive bulk tanks found in our study was similar to those reported in other countries (Fox 2012), further studies are needed to find out the real prevalence of Mycoplasma in Chile.

We found only one bulk tank milk positive for $M$. bovis, which indicates that there is, at least, one cow with Mycoplasma mastitis in the herd, so it would be advisable to identify all infected animals and segregate or remove them from the herd (Fox 2012, Nicholas et al 2016). M. bovis causes more severe cases of intramammary infections due to Mycoplasma, and has been associated with respiratory infections, otitis, septic arthritis, and reproductive infections in cattle (Nicholas and Ayling 2003, Maunsell et al 2011). Intramammary infection due to Mycoplasma bovis is feared by dairy farmers and veterinarians because it is highly contagious, hard to control and there are still no vaccines available, as for other udder pathogens (Mella et al 2017).

In addition, this study describes for the first time in Chile the isolation of $M$. bovigenitalium and $M$. alkalescens. $M$. bovigenitalium has been documented as a cause of diseases in dairy herds, mainly associated to genital tract infections (Lysnyansky et al 2009) and cases of clinical mastitis (Baumgartner et al 2006, Lysnyansky et al 2016). It is one of the three most isolated Mycoplasma species from bulk milk tanks, with an isolation frequency that varies between $1 \%$ and $25 \%$ (Fox 2012). Occasionally, $M$. bovigenitalium and $M$. alkalescens can be isolated from milk samples, but not always their presence is associated with disease (Lysnyansky et al 2016). However, in our report M. alkalescens was isolated from cows with subclinical mastitis that had negative cultures results to other common mastitis pathogens, so it is likely to be the causative agent of intramammary infection in these animals.

In conclusion, Mycoplasma mastitis is a potential risk for dairy herds in southern Chile since, although in low percentages, the agents are present in the herd environment. It is important to note that not only M. bovis is present in these dairy herds, but also other pathogenic species not previously described in Chile such as M. bovigenitalium and $M$. alkalescens. Consequently, diagnostic laboratories should attempt to isolate Mycoplasma spp. when testing milk samples from cows with clinical mastitis that do not respond to antibiotic treatment.

\section{ACKNOWLEDGEMENTS}

The authors would like to thank the PROLESUR company personnel. This research was funded by FIA CS-2004-1-P-001/M3P4.

\section{REFERENCES}

Abd El Tawad AA, El-Hofy FI, Hassan NI, El-khayat ME. 2019. Prevalence of Mycoplasma bovis in bovine clinical mastitis milk in Egypt. Behna Vet Med J 36, 57-65.

APHIS-USDA. 2008. Prevalence of contagious mastitis pathogens on U.S. dairy operations, 2007. APHIS Info Sheet No. 533.1008 . APHIS-USDA, Fort Collins, CO, USA.

Baumgartner M, Winter P, Baumgartner W, Rosengarten R, Spergser J. 2006. Enzootisch verlaufende Mastitis durch Mycoplasma (M.) bovis und M. bovigenitalium in einem österreichischen MilchviehbetriebEin Fallbericht. Wien Tierarztl Monat 93, 18-25.

Boonyayatra S, Fox LK, Gay JM, Sawant A, Besser TE. 2012. Discrimination between Mycoplasma and Acholeplasma species of bovine origin using digitonin disc diffusion assay, nisin disc diffusion assay, and conventional polymerase chain reaction. $J$ Vet Diagn Invest 24, 7-13.

Botes A, Peyrot B, Olivier A, Burger W, Bellstedt D. 2005. Identification of three novel mycoplasma species from ostriches in South Africa. Vet Microbiol 111, 159-169.

Bustos K, Muñoz M. 2011. Prevalence of Mycoplasma spp. in bulk tank milk from dairy farms of the Biobio Region of Chile. Proceedings of the $52^{\text {nd }}$ National Mastitis Council Annual Meeting, San Diego, California, USA, Pp 151-152.

Filioussis G, Christodoulopoulos G, Thatcher A, Petridou V, BourtziChatzopoulou E. 2007. Isolation of Mycoplasma bovis from bovine clinical mastitis cases in Northern Greece. Vet J 173, 215-218.

Foddai A, Idini G, Fusco M, Rosa N, De la Fe C, et al. 2005. Rapid differential diagnosis of Mycoplasma agalactiae and Mycoplasma bovis based on a multiplex-PCR and a PCR-RFLP. Mol Cel Probes $19,207-212$.

Fox LK, Hancock DD, Mickelson A, Britten A. 2003. Bulk tank milk analysis: Factors associated with appearance of Mycoplasma sp. in milk. J Vet Med B Infect Dis Vet Public Health. 50, 235-240.

Fox LK. 2012. Mycoplasma Mastitis: Causes, transmission, and control. Vet Clin Food Anim 28, 225-237.

Gille L. 2018. Mycoplasma bovis: Sources of infection, prevalence and risk factors. PhD Dissertation, Faculty of Veterinary Medicine, Ghent University, Belgium.

González RN, Wilson DJ. 2002. Realistic milk culture programs for herd expansion. NMC. Proceedings of the $41^{\text {st }}$ Annual Meeting National Mastitis Council, Orlando, USA, Pp 118-124.

Hogan SJ, González NR, Harmon JR, Nickerson CS, Oliver PS, et al. 1999. Laboratory Handbook on Bovine Mastitis. Revised Edition, National Mastitis Council, Madison, WI, USA

Kim M, Oh HS, Park SC, Chun J. 2014. Towards a taxonomic coherence between average nucleotide identity and 16S rRNA gene sequence similarity for species demarcation of prokaryotes. Int J Syst Evol Microbiol 64, 346-351.

Lysnyansky I, Brenner J, Alpert N, Benjamin A, Bernstain M, et al. 2009. Identification of Mycoplasma bovigenitalium and Mycoplasma canadense from outbreaks of granulopapular vulvovaginitis in dairy cattle in Israel. Vet Rec 165, 319-322.

Lysnyansky I, Freed M, Rosales R, Mikula I, Khateb N, et al. 2016. An overview of Mycoplasma bovis mastitis in Israel (2004-2014). Vet $J$ 207, 180-183.

Maunsell FP, Woolums AR, Francoz D, Rosenbusch RF, Step DL, et al. 2011. Mycoplasma bovis infections in cattle. J Vet Intern Med 25, 772-783.

Mella A, Ulloa F, Valdés I, Olivares N, Ceballos A, et al. 2017. Evaluation of a new vaccine against Staphylococcus aureus mastitis in dairy herds of southern Chile. I. Challenge trial. Austral J Vet Sci 49, 149-160.

Murai, K, Higuchi H. 2019. Prevalence and risk factors of Mycoplasma bovis infection in dairy farms in northern Japan. Res Vet Sci 123, 29-31.

Nicholas RA, Ayling RD. 2003. Mycoplasma bovis: disease, diagnosis, and control. Res Vet Sci 74, 105-112. 
Nicholas RA, Fox LK, Lysnyansky I. 2016. Mycoplasma mastitis in cattle: To cull or not to cull. Vet J 216, 142-147.

Parker AM, Sheehy PA, Hazelton MS, Bosward KL, House JK. 2018. A review of Mycoplasma diagnostics in cattle. J Vet Intern Med 32, 1241-1252.

Passchyn P, Piepers S, De Meulemeester L, Boyen F, Haesebrouck F, et al. 2012. Between-herd prevalence of Mycoplasma bovis in bulk milk in Flanders, Belgium. Res Vet Sci 92, 219-220.

Razin S, Yogev D, Naot Y. 1998. Molecular biology and pathogenicity of Mycoplasmas. Microbiol Mol Biol Rev 62, 1094-1156.
Sickles S, Kruze J, González R. 2000. Detection of Mycoplasma bovis in bulk tank milk samples from herds in southern Chile. Arch Med Vet 32, 235-240.

Timonen AAE, Katholm J, Petersen A, Mötus K, Kalmus P. 2017. Withinherd prevalence of intramammary infection caused by Mycoplasma bovis and associations between cow udder health, milk yield, and composition. J Dairy Sci 100, 6554-6561.

Wilson D, Goodell G, Justice-Allen A, Smith S. 2009. Herd-level prevalence of Mycoplasma spp. mastitis and characteristics of infected dairy herds in Utah as determined by a statewide survey. $J$ Am Vet Assoc 235, 749-754. 
